\title{
Human Security, Poverty Pattern and Social Order in Igbo Rural Communities of Contemporary Nigeria
}

\author{
Iwundu Anthony Onyekwere \\ Imo State University, Owerri, Nigeria
}

\begin{abstract}
The Igbo have their homeland in seven states of Nigeria mainly Imo, Abia, Anambra, Ebonyi, Delta and Rivers. They are receptible to new ideas and adapt easily to change. The ramifications of human insecurity, poverty, social disorder, poor coherence and poor integration appear to haunt them and the gravity is felt more in the rural communities. The factors are traceable to many pathetic issues. The pathological consequences do affect Igbo stability and navigation in the Nigerian socio-economic environment. The causality constitutes the physical, human, natural, financial and social assets. It is recommended, among others, that the people should return to core values and norms, stick to their own noble identities, have a framework for tackling insecurity and hunger, target the youth in poverty reduction measures and tackle the herdsmen menace. Equally, the abused philosophies used to support dangerous and strange behavior should be tackled.
\end{abstract}

Keywords: human security, poverty pattern, social order, rural community, assets, integration

\section{Introduction}

The Igbo have their homeland in seven states of contemporary Nigeria, viz: Imo, Abia, Anambra, Ebonyi, Enugu, Delta, and Rivers. They also constitute major settlers in many cities in Nigeria. They are great travelers. They are competitive and industrially minded. They have an egalitarian orientation but materialistic. They have an innate receptivity to new ideas and adaptability to change as well as a zeal for continuous improvement. They often manifest shouty life styles. The Christian religion which arrived in Igbo home areas in the later part of the 19th and early 20th centuries have since become their primary religion. Politically the Igbo have a few traditional state societies while remaining primarily acephalous. The few state societies are Onitsha, Aboh, Oguta and Arochukwu.

Colonialism and post colonialism brought them under Anglo-American fashioned political organizations. Between 1954 and 1966 it was the parliamentary system of government while from 1979 to 1983 and again 1999 to date it has been presidential system of government. The Igbo also shared in the unitarism of the long military regime in Nigeria. The military mind, soaked with aggression, violence and associated military-type political administration, affected the personality of the Igbo, making many to care less about the feeling of others and generating a bohemian civilian class long after the military had left.

The Igbo rural communities share in the over all human insecurity and poverty pattern of Nigeria and peoples. Okunmadewa et al. (2002) listed insecurity as one major cause of ill-being or poverty in Nigeria. It has been consistently reported that majority of the poor in Nigeria live in the rural areas (National Bureau of

Iwundu Anthony Onyekwere, Ph.D., Department of Sociology, Imo State University. 
Statistics, 2007, pp. 37-43). Insecurity and poverty have been appearing as correlates and tend to reinforce each other. The insecurity is traceable to deviations from Igbo ethnic norms and values, acquisition of military psyche, activities of politicians, state misrule, emergence of gang groups and cultists, income uncertainties, grazing privileges to Fulani/Hausa herdsmen. Poverty is traceable to insecurity and crime, low health, lack of freedom and oppression, mis-governance and weak community social institutions. Disorder and poor social coherence have been accompanying all these, a situation that affects goal attainment and interest articulation.

Theoretically, this study is explained by differential social disorganization model popular with deviant studies. By this, insecurity, order and disorder are rooted in social organization of the people, thus the people may be organized for order or disorder. Out of disorder the poor would emerge. The deviations from the norms of security also manifest.

This writer looks at the ramifications of human security and poverty pattern as they relate to social order, social cohesion and social integration and how they altogether limit the Igbo, especially the rural dwellers. The study is important when it is realized that insecurity weakens social capital and brings to vulnerability the natural, human, physical and financial capital. What is more, in the face of insecurity in the rural, the urban suffers because rural assets do much of the urban supply.

\section{Human Security and Poverty Pattern}

Human security refers to the safety of life as evidenced in civil peace, physical safety, guarantee of human rights and the environment, ease to justice, guarantee of a secure old age, confidence in the days ahead, reduced vulnerability, of fear and anxiety. The definition given by Commission on Human Security cited by Severine Denuelin is insightful, thus: absence of violence, presence of good governance, access to education and health care, ensuring that individuals have opportunities and choice to fulfill own potentials, freedom from want, freedom from fear and the freedom of future generations to inherit a healthy natural environment (Deneulin, 2009, p. 93). Deepa Narayan and Patti Petesch present the following as elements of security: living in fear, atrocities of police and the army, the capture of state resources by state representatives, deterioration of law and order, thirst for quick justice, gender based violence and abduction (Narayan \& Petesch, 2010).

The above issues to a large extent are evident in Igbo home areas and states including the rural communities, people live in fear of hostile neighbors, cultists, kidnappers, rapists, armed robbers, militant politicians, Fulani herdsmen and youth gangs. A group of bohemian state representatives capture state resources leaving the people lost, deprived, in discomfiture and traumatized. These issues are easily exemplified. Habeeb Pindiga published a statistics that "Nigerian Federal legislators receive much higher salaries than their counterparts in wealthier countries; in terms of lawmaker's salaries as a ratio of GDP per capita, the gap is even much wider. While the salary of a Nigerian lawmaker is 116 times the country's GPD per person, that of a British member of parliament is just 2.7 times; add these to other allowances, frivolous foreign trips arbitrary appointment of aids and use of excessive motorcades" (Habeeb, 2013, p. 64). Government representatives of Igbo abstraction benefitted from these schemes but would not employ their largesse wisely, rather they would be casting terror on their people especially the rural dwellers.

Let us consider, further, the aggravated hostilities that accompanied creation of autonomous communities in Igbo speaking states beginning from the mid 1990s to present. The quarrels and hate are yet to soothe. Definitely politics and democratization, including creation of autonomous communities, brought about a lot of opportunities but opened up new fault lines. In many communities ancient inter and intra land disputes have 
been resurfacing with open hostilities, and reprisals. Cultists and hired assassins are gradually replacing thugs as instruments for settling disputes and vendetta. The return to democracy saw many politicians arranging for armed guards and militant wings, an outfit that creates tension in communities. Armed robbers in the south east have moved some steps further. They go into banks with dynamites, gas cylinders, brick slizing machines and iron cutting machines. Imagine the desperation to destroy commonly owned property in order to rob. Abduction and kidnapping, slavery and trafficking have continued to take new dimensions. By all these we begin to witness a gross decline in social morality and the social contract between people and government and such can be infections.

The impact of all these in our communities could be grave. Farm lands are abandoned in major food basket areas of Imo State such as Ohaji, Obinze, Mgbirichi, the satellite garden community of Irete as well communities in Ebonyi State because of armed Fulani herdsmen. Youth gangs attack and rape women in Mgbuishi, Ohaji of Imo State and prevent them from farming. It was reported that the gang had to over run a local police unit (The Leader, 2014). Resources meant for community development are spent on the leisure of politicians. The methodology of execution of crimes shows how the Igbo proverbial dogged energy, competiveness and inventiveness is now being channeled into vices at the expense of science, technology and humanity. The overall climate of fear, de-motivations and discouragement to repatriate money is captured by Pius Okaneme thus:

Most of the successful indigenes from south-east living outside the zone are frightened to visit home. Wealthy people have relocated their loved ones to presumably safer zones... the desire by many Igbo people to amass wealth in big cities and come back home and show their folks that they have succeeded had been known to be a strong motivation. (Okaneme, 2013, p. 20)

The bad security situation in Igbo rural communities have been affecting rural based industries forcing many to shot down. People in the communities are frightened to attend meeting where community matters are discussed; people run morbid fear and worries that affect the development of ideas. It should be noted that insecurity in rural communities hit women and children strongly. They are there more than the men. Above all they do more of the farming, harvesting and post harvesting activities. If they are chased out by insecurity the situation would be grave for Igbo speaking states. Even agro-urban supplies will reduce. One should also be worried that in the face of insecurity vulnerability to declines in wellbeing is increased. The strong link between human security and human development is buttressed by Adedaya Adedoyin thus: "human security is essential for every sustainable development plan, a precondition for people's improvement particularly the poor" (Adedoyin, 2012).

\section{Poverty Pattern}

An over arching conception of poverty is needed in this study. The World Bank defines poverty as:

A denial of choices and opportunities, a violation of human dignity, lack of basic capacity to participate effectively in society, not having enough to feed or cloth a family, not having a school or clinic to go to, not having the land on which to grow one's food or a job to earn one's living, not having access to credit; insecurity, powerlessness and exclusion of individuals, households and communities; susceptibility to violence; living in marginal or fragile environments, without access to clear water or sanitation. (The World Bank, 2007)

Poverty patterns are difficult to describe in view of absence of poverty maps in Nigeria. However the pattern goes with the level of presence of the characteristics and manifestations of poverty. Initial conditions for poverty are more in certain communities and households than others. Some places and households have more 
locational advantages than others. Government infrastructures and missionary initiatives like schools, markets, hospitals, roads may have reached certain places earlier than others, thus giving them a leap. There is therefore communities and households with more educated heads, more working class heads, water and sanitation, nutritional opportunities electricity and reduced sizes than others. There are also places/households that have more persons in the formal economic activities; places that experience more seasonal and environmental stresses and shocks than others. There are places that have more girl/women education and where women have access to social amenities. In many places the presence of police would serve as assurance for human safety or serve as trigger for violent conducts. Some communities and households are known to have more disregard for traditional values than others. Some communities have more informed persons than others, an indication of safety nets and secure livelihoods.

Levels of violence, conflict and disorder tend to move along these lines. This is confirmed by Foluso Okunmadewa et al. reports about Nigeria, thus: "in some villages crime is considered to be on the increase due to disregard for traditional values, growing impoverishment, widespread disobedience among youths. Corrupt and abusive police are related to illegal arrests and intimidation" (Okunmadewa et al., 2002, pp. 99-100).

\section{Social Order and Social Cohesion}

Social order and social cohesion are not significantly separable. Social order is about how social structures are integrated and maintained while social cohesion is about how parts of the society are held together using common interests and values. Dennis Wrong views social cohesion as how social and moral order are accomplished, social integration achieved and whether societies become divided or united. To Dennis Wrong the problem of or order becomes resolved in everyday associations that maintain regular life rather than being minimal and occasional contacts (Wrong, 1994). Kurt Back articulates that cohesion is a certain pattern of relationship of which the denser the pattern the stronger the relationship and the more cohesion that is expected within the group (Back, 1977). Kurt Back further gives certain conditions of cohesion which are instructive for the Igbo.

- Through instruction during which subjects are told how they resemble; they are promised of joint reward so as to become more independent and appreciate interdependence.

- Common threat. Threat, especially an outside enemy, can increase group cohesion.

- Positive action, people are induced through positive actions like creating warm atmosphere, to love one another (Back, 1977, pp. 115-117).

The Igbo came closest to number two conditions above, a common enemy, during the Nigerian civil war of 1967-1970. That alone took care of any other condition. The people hoped for wealth and human flourishing. They appreciated interdependence; they showed warmth and love.

\section{Maintaining Cohesion}

Social structure is implicated in the issues of social order and cohesion. Man is at the centre of structures. He approaches its maintenance through two models-consensus and conflict. For consensus, reasoned Margaret Peil, members are seen to share in the same values and norms; co-operation is rewarding and society is basically stable. Even when conflict and violence occur, continued Margaret Peil, they are contained and eventually overcome. On the side of conflict, it is argued that values and norms are not same for all members of society but vary according to interests and positions in that forms of social organization provide more for some persons than for others, thereby making conflict inevitable (Peil, 1977). 
All known societies contain elements of cohesion and conflict. However, one form may dominate at one time than the other depending on the pattern of allocation of weberian type economic, prestige and power resources. Conflicts over interests, even ideas may begin to threaten human security. Insecurity tears down the social order. This is where the Igbo communities are. The questions ahead are: Could order be restored and how would the people begin to re-cohere? What pathological consequences are being witnessing? Dennis Wrong while commenting on "what units and divides of society, informs that order is always a matter of degree, coexists with and influences and is influenced by individual deviance, group conflict, social change and cultural innovation" (Wrong, 1994). Dennis Wrong also pointed at the factor of withdrawing from an initial identity and moving into a new one as a causation. He reasoned further that the problem of order could not ignore human nature and the processes by which it is formed through contacts. Dennis Wrong pointed at anarchy, anomie, crime waves, insurrections, revolutions and civil wars, riots, mob violence and other kinds of unconventional behavior as instances of breakdown and collapse of order (Wrong, 1994). In a comparable contribution on what units and divides, Cante, cited in Coretta Phillips states that the problem of changing attitudes and values are at the root of lack of community cohesion (Philips, 2013).

All these issues and factors appear to have been playing out among the Igbo. The people for many years have been abandoning their own identity patterns and taking up strange ones just to belong or be accepted by those who conquered them in the civil war. Though it is often said that the Igbo need some levels of diplomacy in their dealings with neighbors, but they cannot be anything less than their own eternal order. If eternal order, which is psychical is assured, a good social order emerges. One notes, in addition, that the Igbo, especially the rural dwellers are primarily sliding into religious/faith identity which is dangerous to order going by its association with anxiety, fear, unreliable prophesies and suggestiveness to withdrawal from mainstream activities.

Pathologically, a wave of hate appear to be pervading the communities; self destruction, especially among the political class is noticed; ambushing and dispossessing genuine investors, inter and intra-group discords are every where. These are aggravated by poverty, hunger and ignorance as well as the continuous splitting of rural communities along autonomous and political ward lines. They are even complicated by abused ideologies as incapsulated in such sayings as:

if one cannot beat them, he joins them; climb the iroko tree and collect all the fire wood (even when the iroko tree is of collective ownership); one can be wealthy at childhood - osina nwata buru agaranya; let the sweet bean cake oil go round-mmanu akara di uto, onye ratu ibeya aratu, a popular slogan among the political class, oblivious of the embarrassment posed to the masses who actually own the 'sweet bean cake oilz'.

The chief casualty in Igbo disorder and poor cohesion is loss of assets/resources. These assets are in the form of:

- Physical assets-material belongings, equipments, housing and infrastructure;

- Human assets-health care, education, training and labour force;

- Social assets-social structures, network connections, use of norms and how people participate;

- Natural assets-environmentally related resources such as land, soil, forests, water, wetland, minerals;

- Financial assets-microfinance products, savings and supplies of credit (Narayan et al., 2000, pp. 48-56; Louise Cord; ${ }^{1}$ Moser, 2008, p. 50).

${ }^{1}$ Louise Cord, "Rural poverty", in a source book for Poverty Reduction Strategies 
Disorder and poor coherence have reduced the availability of these resources. The most implicated are social and human capital because they have overriding influence on others, serving as informal insurance on them. The extent to which social capital, for example, ties others is captured by Vinod Thomas, et al. thus:

Few resources are spent to protect against economic fraud; monitoring of supplies become easy; inter personal trust, participation and co-operation are built; diffusion of innovation and information are guaranteed. (Thomas et al., 2000, p. 33)

A return to group cohesion can be achieved through instructions from Talcott Parsons on return to value consenus and adherence to social functional prerequisites mainly adaption, goal attainment, integration and pattern maintenance (Haralambos \& Holoborn, 2004, p. 940). Adopting the Parsonian conceptions above, the Igbo would arrive at shared values, then common goals are set and these goals provide direction in specific situations. The adaptation prerequisite suggests that the Igbo would relate well with their environment, provide food, shelter and security for the service of the people. For goal attainment, goals are set and social activity is directed on such and resources allocated on such activities too. Integration suggests that parts of the system (Igbo social system) continuously adjust in relation to conflicts; define norms properly and standardize relations so that conflicts do not lead to disintegration of society, pattern maintenance suggests the maintenance of basic values of the people through the family institution, the educational system and religion.

\section{The Problem of Social and System Integration}

How are social and system integration implicated in the Igbo problem of insecurity and social order? How does poverty come in? What is the balance between internal and external disequilibria of Igbo life and what are the implications for survival? John Scott and Gardon Marshall consider "social integration as the principles by which individuals or actors are related to one another in a society while system integration is the relationship between parts of a society or parts of system" (Scott \& Marshall, 2005, p. 655). John Scott and Gordon Marshall further opines that during social integration actors are physically co-present while for system integration they are not. Barry Barnes reasons that social integration is about how and why individuals in the system produced the actions necessary to its existence while system integration is about how parts of a social system, the constiment institutions operate in relation to each other (Barnes, 1995).

Both social and system integration do overlap and embrace all of orders, conflict, harmony and contradictions. In what ever forms, we expect these to be positive for Igbo survival. Unfortunately, so many forces are not being mitigated against. One is the problem of post-colonialism which pushed the Igbo into crass materialism. A conflictual social integration is expected for a people that embraced crass materialism (Scott \& Marshall, 2005). Secondly the Igbo appear not to be mitigating the forces of internal and external disequilibria. The forces of internal disequilibrium which appear to call for regulation are the nascent strange business character, reign of hobbessian free passions, bad political ethics and ideologies, institutionalization of killer groups like hired assassins and cultists, anti-people religions groups.

The forces of external disequilibrium are due to the macro social and economic policies of the federal government which the Igbo states are part of. One recalls rice policies that do not promote Igbo Akaeze and Abakiliki rice; stock fish and vehicle spare parts importation policies concerning a business area that is the domain of the Igbo; cattle and meat policies that have ignored the promotion of Igbo indigenous cow; science and technology policies that do not promote the Igbo content; 
Without integration and the mitigation of both internal and external forces, the Igbo, especially rural dwellers are likely to slide deeper into cultural confusion and poor fare situation in the years ahead, cultural confusion in the sense that the Igbo are left with:

A mongrelized, extroverted, foreign-dominated culture, a culture without respectability, a culture without economic strength and political power, a culture with no intellect and of incomplete synthesis. A poor fare state in the sense that there is an equal distribution of poverty, consumerism, parasitism and competitive factionalism and intensification of instability and anti-cohesive ethnic politics. (Chinweizu, 1978)

\section{Conclusion and Recommendation}

A lot of ambivalence is faced by the Igbo in view of insecurity, poverty and social disorder that are occurring simultaneously, moreso when the state is weak and can no longer be relied upon. The reinforcing nature of these is threatening Igbo survival and pushing them into fatalism. Disorder has been created by divergent interests, post colonial crass materialism, inconsistent ideas and values; the jettisoning of own identity patterns and picking new, often strange ones. Insecurity and poverty share in the same causative agents. Insecurity affects poverty escapes, hinders the freeman and lawful industry and tears down the social order. Conflictual forms of social integration are expected in societies that purse crass materialism.

\section{Recommendations}

The Igbo have a responsibility to restore order in their homelands, beat down poverty and achieve social cohesion. The following must be done:

- The people must work towards conformity to core group norms which are the key to system stability. This must be done over and against the promptings of rational self interests.

- Persons in power in the south east states must share ideas and strategies, even a clearing office. A good example was when they simultaneously accepted to demolish the houses of kidnappers.

- Eastern government should create livelihood opportunities for the poor, recognizing the fact that poverty is not just about income. They also need to invest in the organization and human capacities of the people to enable them check the erosion of assets that have come under threat.

- Contacts among Igbo and among social institutions must be encouraged while at the same time fashioning out how to distinguish what is Igbo and non Igbo, such as the use of language and any symbols.

- Igbos should stick to their noble identity endowments, refuse to compromise or play safe. The ignoble trends should be jettisoned.

- Poverty reductions plans by governments should be targeted at the youth, in view of their role in insecurity.

- A programme of reintegration of gang leaders and men, cultists, former political militants and thugs should be organized by local government authorities via community councils.

- The Eastern states should create ranches for herdsmen and put up an adequate value chain for the cow industry so that Eastern economies of Nigeria will benefit.

- The abuse of Igbo philosophical sayings and using such to support strange conduct should be tackled by specifying their contextual usage, and limits, Igbo socio-cultural organizations and relevant agencies should be involved. 


\section{References}

Adedoyin, A. (2012). Development and security in the Nigerian democratic dispensation. The Nigerian Journal of Sociology and Anthropology, 10, 103-105.

Back, K. (1977). The social psychology. London: John Wiley and Sons, Inc.

Barnes, B. (1995). Elements of theory. New Jersey: Princeton University Press.

Chinweizu, I. (1978). The West and the Rest of US. London: Nok Publishers.

Commission on Human Security. (2003). Protecting and empowering people. Retrieved from http://www.humansecurity-chs.org

Cord, L. (1992). Rural poverty. In J. Klugman (Ed.), A source book for poverty, reduction stratagies (Vol 2): Macroeconomic and sectoral approaches (pp. 55-99). Washington: The World Bank.

Deneulin, S. (2009). Ideas related to human development. In S. Deneulin \& L. Shahani (Eds.), An introduction to human development and capability approach (pp. 22-48). UK and USA: Warthscan Publisher.

Habeeb, I. P. (2013). Nigerian Lawmakers top salaries chart...beat MPs in US, Britain, S/Africa, Brazil, Japan. Daily Trust, July 22.

Haralambos, M., \& Holoborn, M. (2004). Sociology: Themes and perspectives. London: Harper Collins Publishers.

Moser, C. (2008). Assets and livelihoods: A framework for asset-based social policy. In C. Moser \& A. A. Dani (Eds), Assets, Livelihoods, and Social Policy (pp. 43-81). Washington, DC: World Bank.

Narayan, D., \& Petesch, P. (2010). Moving out of poverty rising from the ashes of conflict. Washington DC: The World Bank.

Narayan, D., Patel, R., Schafft, K., Rademacher, A., \& Schulte, S. K. (2000). Voices of the poor: Can anyone hear us? Washington, DC: World Bank/Oxford University Press.

National Bureau of Statistics. (2007). Nigeria Poverty Assessment, 2007. Abuja: Federal Republic of Nigeria Press.

Okaneme, P. (2013). Igbos, kidnapping and climate of fear. The Nation, September 27.

Okunmadewa, F., Aina, O., Ayoola, G. B., Mamman, A., Nweze, N., Odebiyi, T., ... Zacha, J. (2002). Nigeria Illbeing and Insecurity. In D. Narayan \& P. Petesch (Eds.), Voice of the Poor From Many Lands (pp. 99-100). Washington, DC: The World Bank.

Peil, M. (1977). Conflict and consensus in Africa societies. Retrieved from http://www.amazon.com/consensus-conflict-africansocieties

Phillips, C. (2013). New directions in race ethnicity and crime. London: Colin Webster.

Scott, J., \& Marshall, G. (2005). A dictionary of sociology. New York: Oxford.

The Leader. (2014). Insecurity: Police escort embattled Mgbuishii Ohaji women home. The Leader, August 15.

The World Bank. (2007). Human and poverty: Definitions and distinctions. Retrieved from http.org/file/hungerandpoverty.pdf

Thomas, V., Dailami, M., Dhareshwar, A., López, R. E., Kaufmann, D., Kishor, A., \& Wang, Y. (2000). The quality of growth. New York: Oxford University Press.

Wrong, D. (1994). The problem of order. New York: The Free Press. 